\title{
Therapeutic efficacy of Chymotrypsin in acute bovine mastitis
}

\section{Eficacia terapéutica de la quimotripsina en mastitis aguda bovina}

\author{
Marco Leal G,* M.Sc.
}

Universidad de Ciencias Aplicadas y Ambientales, U.D.C.A. Facultad de Ciencias Pecuarias. Calle 222 No. 55-37 Bogotá, Colombia. *Correspondence: mleal@udca.edu.co.

Received: April 2015; Accepted: November 2015.

\section{RESUMEN}

Objetivo. Evaluar la eficacia terapéutica del fármaco proteolítico "quimotripsina", en tratamientos conjuntos con un antibiótico betalactámico en vacas con mastitis aguda. Material y métodos. Se evaluaron el conteo de células somáticas (CCS) y los hallazgos semiológicos, comparando la eficacia con un grupo de animales en donde sólo fue utilizado el antibiótico. Resultados. Los resultados revelaron eficacia clínica (disminución del CCS, p <0.01) y ausencia de signos clínicos agudos en el $84.7 \%$ de los cuartos observados, incluso observándose respuesta anti-inflamatoria desde las primeras horas del tratamiento. El restante $15.3 \%$ también presentó eficacia clínica a la terapia aunque la respuesta fue moderada en comparación con el $84.7 \%$ de los casos que tuvieron la respuesta acelerada. Conclusiones. Lo anterior permite concluir que el uso de quimotripsina en casos de mastitis aguda, acelera la respuesta en la glándula mamaria infectada e inflamada, con mayor eficacia que los tratamientos con sólo amoxicilina + ácido clavulánico.

Palabras Clave: Fármaco, producción, terapia (Fuente: UNESCO).

\section{ABSTRACT}

Objective. To evaluate the therapeutic efficacy of a proteolytic drug "chymotrypsin" combined with beta-lactam antibiotics in cows with acute mastitis. Material and Methods. Fourteen cows with acute mastitis. Three cows were treated with a beta-latam antibiotic (BLA) and the other eleven cows were treated with chymotrypsin plus beta-lactam antibiotic ( $C+B L A)$. The response was evaluated according to the semiological findings, somatic cell count (SCC) and a microbiological culture. Results. There was a therapeutic efficacy comparing the pre and post treatment period (SCC reduction, $\mathrm{p}<0.01$ ) and a reduction of clinical signs in $84.7 \%$ of treated quarters in the first day of treatment (C+BLA) compared with (BLA). Conclusions. Chymotrypsin improves the treatment of acute mastitis when is combined with BLA, controlling the infected mammary glands, compared with the group treated only with amoxicilina and clavulanic acid.

Key words: Drug, production, therapy (Source: UNESCO). 


\section{INTRODUCTION}

Mastitis is one of the most important diseases affecting cattle production. This problem is reduces milk quality and quantity and ha a negative impact in dairy business (1). This pathology is defined as inflammation of the mammary gland, due to no infectious (traumatic) and infectious agents, including bacteria such as Staphylococcus aureus, Escherichia coli, Streptococcus dysgalactiae, S. uberis, Arcanobacterium pyogenes, Klebsiella spp., mycoplasmas, yeasts and algae (2). All these microorganisms are capable to colonize the udder, increasing the number of somatic cells, mainly neutrophils and epithelial cells.

Sub-clinical mastitis is one of the main problems of milk production. In a herd with an average production of $8500 \mathrm{~kg} / 305$ days and cell counts greater than 200,000 cells/ml, losses can reach US \$22 (USD) per animal/ year. During subclinical presentation, the udder shows no signs of inflammation and milk may appear normal. In contrast, in clinical mastitis the infected quarter is inflamed, some cows manifest tenderness and milk is visibly altered (3). In severe clinical cases (acute mastitis), the cow shows generalized symptoms including fever, elevated heart rate, loss of appetite and significant reduction in milk production with a dramatic increase in somatic cell production (4), classic signs of inflammation can be found as well as alterations in milk, identified as lumpy (dairy clots due to the inflammatory process). When the disease becomes chronic, inflammation can affect the immune system (5) and causes resistance to almost any treatment. Additionally, can result in anatomopatolhogical and physiological problems, such as the formation of fibrous tissue, cell destruction and necrosis (6).

The bases for the Control of Contagious Mastitis in the UK consist of a five-point plan for prevention and management, also mentions the importance of using antimicrobials during the stages of lactation and drying when necessary (7). However, field veterinarians know that antibiotics sometimes are not enough and that it is necessary to treat the inflammation using NSAIDs and glucocorticoids, and the treatment of particular cases with proteolytics (chymotrypsin) that have proven highly effectiveness.

The major intramammary antimicrobial treatments that have been used with different success rates to control bovine mastitis include beta-lactams such as natural $G$ penicillins

\section{INTRODUCCIÓN}

La mastitis es una de las enfermedades de mayor relevancia e investigación en la Medicina de la producción en bovinos. Su impacto sobre la calidad y cantidad de la producción láctea mundial afecta de manera directa la rentabilidad del negocio lechero (1). Definida como la inflamación de la glándula mamaria, puede ser de diversas etiologías entre las que se encuentran bacterias como Staphylococcus aureus, Escherichia coli, Streptococcus dysgalactiae, S. uberis, Arcanobacterium pyogenes, Klebsiella spp., mycoplasmas, levaduras y algas (2). Todos estos microrganismos son capaces de colonizar la glándula mamaria y producir incremento del número de células somáticas, principalmente macrófagos, neutrófilos y células epiteliales.

Tan sólo, la mastitis sub-clínica ha sido catalogada como uno de los principales enemigos de la producción de leche, llegando a generar pérdidas dependientes del número de glándulas mamarias que posean incremento en el conteo de células somáticas. Para una finca con un promedio de producción de $8500 \mathrm{~kg} / 305$ días y conteos de células superiores a 200000 células/ml, las pérdidas pueden alcanzar alrededor de los $\$ 22$ dólares americanos (USD) por animal/año. Durante la enfermedad subclínica la ubre no muestra ningún signo de inflamación y la leche puede parecer normal. En contraste, en la mastitis clínica, el cuarto infectado se inflama, en algunas vacas se manifiesta dolor a la palpación y la leche se encuentra visiblemente alterada (3). Esta mastitis clínica puede ser en los casos clínicos más severos (mastitis sobre-aguda), la vaca muestra signos generalizados: fiebre, elevación de frecuencia cardíaca, pérdida de apetito y reducción significativa de la producción de leche con incremento dramático en la producción de células somáticas (4). En la aguda, pueden encontrarse los signos clásicos de la inflamación además, de alteraciones en la leche que en el presente artículo fueron identificados como grumos (coágulos lácteos debidos al proceso inflamatorio). En los casos en que la enfermedad se hace crónica, la inflamación puede afectar la respuesta inmune (5) al grado de generar en la glándula una resistencia a casi cualquier tratamiento. Adicionalmente en la ubre inflamada de manera aguda y especialmente en la forma crónica pueden producirse cambios estructurales que alteran su fisiología, como la formación de tejido fibroso e incluso la destrucción celular y necrosis (6).

La Fundación para el Control de las Mastitis Contagiosas en el Reino Unido, desarrolló un plan de cinco puntos relacionados con los métodos preventivos y de manejo, pero adicionalmente enfatiza en la necesidad de utilizar antimicrobianos 
(sodium, potassium, procaine and benzathine), synthetic ones such as ampicillin, amoxicillin and anti-staphylococcus drugs (cloxacillin, oxacillin, nafcillin, meticillin); cephalosporins (Cefapirin, cefalonium, cephalothin, cefoperazone, ceftiofur, cefquinome); aminoglycosides such as dihydrostreptomycin, gentamicin and neomycin; aminocoumarins (novobiocin); fluoroquinolones (norfloxacin); tetracyclines (oxytetracycline); macrolides (erythromycin); lincosamides such as lincomycin and pirlimycin; chloramphenicol, among others.

Additionally, anti-inflammatory treatments in cases of mastitis is usually common and necessary. Anti-inflammatory drugs such as carprofen can be used to accelerate recovery of mammary glands in concomitant therapies with antibacterial drugs. Meloxicam is also recommended. These medicines help to decrease somatic cell counts better than with a single antimicrobial treatment (8). During the inflammatory process, the release of bacterial endotoxin causes systemic symptoms such as elevated body temperature, decreased ruminal motility, and even increased heart and respiratory rates. Therefore, using drugs that not only have anti-inflammatory but also antiendotoxemic properties can speed up the recovery process. Among the commonly used drugs in the United States that have these characteristics, flunixin meglumine also has analgesic, antiinflammatory and antipyretic properties (9) that accelerates gland recovery and bacterial elimination. Others, such as ketoprofen, also have a recognized antiendotoxemic action (10), and its analgesic effect is important to improve udder health and milk production (11).

Additionally, glucocorticoids have been employed in parenteral (12) and intramammary (13) formulas due to greater anti-inflammatory action compared to non-steroidal drugs.

Meanwhile, proteolytic enzymes have been considered as an effective treatment for bovine mastitis (14). Among the mean enzymes there are trypsin, chymotrypsin and papain, which have fibrinolytic and proteolytic activity on inflamed tissues (15). Bovine pancreatic chymotrypsin is the active ingredient in Quimotripsyn $®$ - Virbac Laboratories, whose action increases plasmin, a proteolytic enzyme of endothelial origin that is responsible for lysing excess of fibrin from the inflammatory process and is considered as the key of fibrinolysis (16).

Regarding to this, it is important to mention durante las etapas de lactancia y secado cuando sea necesario (7). Sin embargo, el médico veterinario de campo conoce que el tratamiento antibiótico en muchas ocasiones no es suficiente y que es absolutamente necesario combatir la inflamación por medio de fármacos como los anti-inflamatorios no esteroidales, los glucocorticoides e incluso existe una amplia experiencia de campo con terapias que han resultado altamente efectivas con el uso de proteolíticos (quimotripsina).

Entre los principales tratamientos antimicrobianos intramamarios empleados con diferentes tasas de éxito para el control de la mastitis bovina se pueden citar, betalactámicos como las penicilinas dentro de las que se encuentran: penicilinas $G$ naturales (sódica, potásica, procaínica y benzatínica), sintéticas como la ampicilina, amoxicilina y penicilinas antiestafilocóccicas (cloxacilina, oxacilina, nafcilina, meticilina); betalactámicos como las cefalosporinas (cefapirina, cefalonium, cefalotina, cefoperazona, ceftiofur, cefquinoma); aminoglucósidos como la dihidroestreptomicina, gentamicina y neomicina; aminocumarinas como la novobiocina; fluoroquinolonas como la norfloxacina; tetraciclinas como la oxitetraciclina; macrólidos como la eritromicina, lincosamidas como la lincomicina y pirlimicina; cloranfenicol, entre otros.

Adicionalmente, los tratamientos anti-inflamatorios en casos de mastitis son comunes y a la vez necesarios. Anti-inflamatorios no esteroidales como el carprofeno pueden ser utilizados para acelerar la recuperación de la glándula mamaria en terapias concomitantes con antibacterianos. Otros como el meloxicam también son recomendados en combinaciones con antibacterianos, debido a que permiten disminuir los conteos de células somáticas con mayor eficacia que con el solo tratamiento antimicrobiano (8). Es bien conocido, que durante el proceso inflamatorio ocurrido durante la mastitis, la liberación de endotoxinas bacterianas es la causa de signos sistémicos como la elevación de la temperatura corporal, disminución de la motilidad ruminal, e incluso el aumento en la frecuencia cardiaca y respiratoria; por tal motivo, utilizar fármacos no solo con actividad anti-inflamatoria sino también anti-endotoxémica, puede acelerar el proceso de recuperación. Entre los fármacos comúnmente utilizados en los Estados Unidos con estas características, está el flunixin meglumina, el cual además, tiene potencial analgésico, antiinflamatorio y antipirético (9); siendo un principio activo que además de acelerar la recuperación de la glándula es capaz de favorecer la eliminación bacteriana. Otros como el ketoprofeno, también poseen una reconocida capacidad antiendotoxémica y pueden ser de utilidad en el momento del tratamiento (10). De igual manera su capacidad 
the relationship between the inflammatory process and coagulation, since fibrinogen and fibrin directly affect the production of cytokines and other proinflammatory substances (TNF-a, IL-1 $\beta$, monocyte chemoattractant protein) in endothelial and mononuclear cells. If there is a fibrinogen deficiency, there would be an alteration in macrophage aggregation and a deficit in immune response, but in the other hand, an excess of fibrinogen would result in anatomo pathological and physiological changes in the affected organ (17). Acute inflammatory processes involve fibrin formation, which is histologically recognized due to an abundant leukocytes and fibrin accumulation. This process should not be confused with fibrosis, which can be chronic (18).

During the inflammatory process in the mammary gland, many tissue factors are activated and stimulate the coagulation cascade and production of thrombin (19). The final phase results in an increase of fibrin and the reduced activity of the fibrinolytic system (20). There have been discovered different processes and mechanisms related to the fibrinolysis suppression on regulatory molecules that activate and inhibit plasminogen (precursor of plasmin) during inflammation, TNF- $a$ and IL-1 $\beta$ (21). Plasmin is derived from plasminogen, which lyses the excess of fibrin produced during the inflammatory process.

When these cytokines (TNF- $a$ and IL-1 $1 \beta$ ) are released into circulation, plasminogen activators are also released from endothelial cells. These activators are known as "tissue-type plasminogen activators" and "urokinase type plasminogen activators" (21). However, it is necessary the release of plasminogen for the fibrinolysis and the release of plasmin is offset by an inhibitor that activates the inflammatory process (22). The resulting effect is a complete inhibition on fibrinolysis and results in an inadequate removal of fibrin which contributes to microvascular thrombosis. In humans, increasing plasmin concentration in blood has been suggested as an effective treatment to dissolve thrombi and has decreased mortality in patients (23).

The use of chymotrypsin activates the production of plasminogen-plasmin and reduces the severity of infections caused by Staphylococcus aureus $(24,25)$, which is considered as one of the main pathogens in bovine mastitis. Now days this mechanism is not yet understood, but it is recognized that elevated plasmin levels can reduce the virulence of $S$. aureus strains (26). It is suggested that plasmin is an important regulator in tissue remodeling and inflammation processes. The present study included cattle with acute mastitis, the use of chymotrypsin was challenged together analgésica es importante para mejorar las condicione de bienestar necesarias para la producción (11).

Adicionalmente, los glucocorticoides han sido empleados en formulaciones parenterales (12) e intramamarias (13) debido a su mayor potencia anti-inflamatoria en comparación con los no esteroidales, con resultados que también colaboran en la respuesta de la glándula mamaria.

Por su parte, el uso de enzimas proteolíticas ha sido establecido como efectivo en tratamientos contra mastitis bovina (14). Entre las principales enzimas, están la tripsina, quimotripsina y papaína las cuales poseen actividad fibrinolítica y proteolítica en tejidos inflamados (15). De ellas, la quimotripsina de origen pancreático bovino, es el principio activo del producto Quimotripsyn ${ }^{\circledR}$ - Laboratorios Virbac, cuyo mecanismo de acción hace que sea incrementada la plasmina, enzima proteolítica de origen endotelial encargada de lisar la fibrina producida en exceso a partir del proceso inflamatorio y que ha sido considerada como la molécula clave de la fibrinólisis (16).

En este punto, es importante mencionar la conexión que existe entre el proceso inflamatorio y el de coagulación ya que el fibrinógeno y la fibrina, directamente influyen en la producción de citoquinas y otras sustancias pro-inflamatorias (TNF-a, IL-1B, proteína quimiotáctica de monocitos), en las células endoteliales y mononucleares. Si el fibrinógeno se encontrara deficiente, se presentarían problemas para la adhesión de macrófagos y la respuesta defensiva normal pero también si el fibrinógeno se encontrara en exceso, se producirían alteraciones fisiológicas en el órgano afectado (17). Es importante recordar que aún los procesos inflamatorios agudos conllevan la formación de fibrina, lo cual se evidencia de manera histológica mediante la presentación de abundantes leucocitos y fibrina. Lo anterior no debe confundirse con fibrosis, la cual puede darse con la cronicidad (18).

Durante el proceso inflamatorio en la glándula mamaria se activan factores tisulares que estimulan la cascada de coagulación y que terminan por producir trombina, enzima que actúa de manera previa a la fibrina (19). Como consecuencia se produce un incremento en la cantidad de fibrina y se deprime el sistema fibrinolítico (20). Esto se observa clínicamente sobre todo a largo plazo como la fibrosis de la glándula. El proceso ha sido estudiado con más detalle, de manera que se han descubierto mecanismos que deprimen la lisis de fibrina a partir de moléculas reguladoras de la activación e inhibición de plasminógeno (precursor de plasmina) durante la inflamación, los cuales son TNF-a e IL-1ß (21). A partir del plasminógeno, se 
with beta-lactam antibiotics in order to assess effectiveness on somatic cell count (SCC), and the semiological findings were compared to a group of animals treated only with antibiotics.

\section{MATERIALS AND METHODS}

Area and study population. The study was conducted on a dairy farm in the savannah of Bogota in the town of Sopó, Cundinamarca, at 2600 $\mathrm{m}$ above sea level and an average temperature of $14^{\circ} \mathrm{C}$. The animals used in this study were Holstein Friesian cattle with an average weight of $550 \mathrm{~kg}$. The cows were milked twice daily in a mechanical milking parlor. A total of 14 cows were evaluated and a total of 46 mammary glands quarter were diagnosed with lumps. In order to establish the severity of mastitis, there was executed the Californian Mastitis Test to determine the changes of the gland before and after treating with chymotrypsin.

Treatment. Once the animals were identified according to inclusion criteria, they were treated with chymotrypsin at a total dosage of $10 \mathrm{ml}$ per animal intramuscularly every 24 hours for 3 applications. Additionally, the animals received 15 $\mathrm{mg} / \mathrm{kg}$ amoxicillin IM every 24 hours for 3 days. There was a total of 3 control animals and a group of 10 with the same characteristics that only received amoxicillin and clavulanic acid, without chymotrypsin.

Laboratory methods. The Californian Mastitis Test (CMT) was executed using a sample of milk of each gland quarter in an special container before washing and blunting the gland. Three $\mathrm{ml}$ of milk were taken from each one on a black CMT tray and an equal amount of CMT reagent (Masti-Test $\AA$ - Laboratorios SFC LTDA) was added, stirring for 5 seconds until the reaction was obtained. To classify the degree of mastitis according to the CMT test, the criteria described by Kivaria et al (27) was developed and explained in table 1 . The CMT was performed minutes before treatment and seven days later.

Table 1. Criteria to classify mastitis in each bovine. Modified (27).

\begin{tabular}{|c|c|}
\hline CMT Score & Test Observations \\
\hline Negative & $\begin{array}{l}\text { Homogenous mix of milk with reactive that showed no } \\
\text { evidence of lumps. Liquid aspect with no thickening. }\end{array}$ \\
\hline Trace & $\begin{array}{l}\text { Slight thickening of the mix that disappears by } 10 \\
\text { seconds. }\end{array}$ \\
\hline 1 & $\begin{array}{l}\text { Lumps form immediately after mixing with no gel } \\
\text { forming tendency. }\end{array}$ \\
\hline 2 & $\begin{array}{l}\text { Lumps formed immediately after mixing and a slight } \\
\text { tendency to form gel. }\end{array}$ \\
\hline 3 & $\begin{array}{l}\text { Lumps formed immediately after mixing and elevated } \\
\text { amounts of gel formed as if it was a fried egg. }\end{array}$ \\
\hline
\end{tabular}

produce plasmina, la cual lisa la fibrina producida en exceso durante el proceso inflamatorio.

Cuando estas citoquinas (TNF-a e IL-1 $\beta$ ) son liberadas a la circulación, se produce la liberación de activadores de plasminógeno a partir de células endoteliales. Estos activadores son conocidos como "activador de plasminógeno tipo tisular" y "activador de plasminógeno tipo urokinasa" (21). Sin embargo, esta liberación de plasminógeno necesaria para la lisis de fibrina y su consecuente liberación de plasmina son contrarrestadas por un inhibidor que activa el proceso inflamatorio (22). El efecto resultante sobre la fibrinólisis es una completa inhibición y como consecuencia la inadecuada remoción de fibrina contribuyendo a una trombosis microvascular. Lo anterior también hace parte de la fisiopatología de muchos procesos inflamatorios e isquémicos y abre la puerta a futuras investigaciones en áreas hasta ahora apenas imaginadas en medicina veterinaria (posibles nuevas indicaciones para el uso de la quimotripsina). Por ejemplo, en seres humanos, el incremento de la plasmina ha sido propuesto como un tratamiento eficaz en la disolución de trombos y ha sido responsable de la disminución de la mortalidad en pacientes (23).

Además, la utilización de la quimotripsina, al activar la producción de plasminógeno-plasmina, es capaz de reducir la severidad de las infecciones producidas por Staphylococcus aureus $(24,25)$, uno de los principales patógenos de la mastitis bovina. Aunque el mecanismo de acción de lo anterior aún no está comprendido, se sabe que la elevación de los niveles de plasmina son capaces de reducir la virulencia de las cepas de $S$. aureus expuestas (26). Incluso, se ha sugerido que la plasmina es un importante regulador en procesos de remodelación tisular e inflamación. En este estudio en bovinos con mastitis aguda, se desafió el uso de quimotripsina en tratamientos conjuntos con un antibiótico betalactámico con el objetivo de evaluar su eficacia sobre el conteo de células somáticas (CCS) y hallazgos semiológicos, en comparación con un grupo de animales en donde solo fue utilizado el antibiótico.

\section{MATERIAL Y MÉTODOS}

Áreas y población en estudio. El estudio fue conducido en una finca lecheras de la sabana de Bogotá en el municipio de Sopó, Cundinamarca, a una altura sobre el nivel del mar de 2600 m y temperatura promedio de $14^{\circ} \mathrm{C}$. Los animales en el estudio fueron bovinos en pastoreo de raza Holstein con peso promedio de $550 \mathrm{Kg}$, con ordeño mecánico, dos veces al día. Se emplearon un total de 14 bovinos y un total de 46 cuartos de glándula mamaria bovina con evidencia de 
Count of somatic cell was done using an electronic DeLaval ${ }^{\circledR}$ counter with a measuring range from 10000 to 4000000 cells $/ \mathrm{ml}$. These samples were collected individually in a tube after eliminating the first spurts of milk.

\section{RESULTS}

Table 2 shows the results according to the degree of Mastitis found in the CMT and somatic cell count before and after treatment with Quimotripsyn ${ }^{\circ}$ and amoxicillin + clavulanic acid. For statistical analysis of somatic cell counts, there was developed an analysis of variance.

Table 2. Results of somatic cell count found in bovines treated with alpha-chymotrypsin.

\begin{tabular}{|c|c|c|c|}
\hline NC & RCMT & $\mathrm{CCS} / \mathrm{ml}$ day 0 & $\mathrm{ccs} / \mathrm{ml}$ day 7 \\
\hline 1 & 2 & 3600000 & 1600000 \\
\hline 2 & 1 & 3200000 & 560000 \\
\hline 3 & Trace & 2160000 & 340000 \\
\hline 4 & Trace & 1710000 & 410000 \\
\hline 5 & Trace & 3620000 & 420000 \\
\hline 6 & Trace & 3120000 & 360000 \\
\hline 7 & 1 & 2240000 & 580000 \\
\hline 8 & Trace & 1100000 & 180000 \\
\hline 9 & 1 & 1400000 & 350000 \\
\hline 10 & 3 & 2140000 & 1230000 \\
\hline 11 & 2 & 3760000 & 1670000 \\
\hline 12 & 3 & 3850000 & 2360000 \\
\hline 13 & Trace & 2690000 & 280000 \\
\hline 14 & 1 & 1520000 & 710000 \\
\hline 15 & 2 & 3710000 & 1020000 \\
\hline 16 & 1 & 3980000 & 560000 \\
\hline 17 & 1 & 3800000 & 630000 \\
\hline 18 & 1 & 4000000 & 1080000 \\
\hline 19 & 1 & 3760000 & 560000 \\
\hline 20 & Trace & 3490000 & 340000 \\
\hline 21 & Trace & 2300000 & 450000 \\
\hline 22 & Trace & 3690000 & 430000 \\
\hline 23 & 1 & 3460000 & 580000 \\
\hline 24 & Trace & 2460000 & 260000 \\
\hline 25 & 1 & 3120000 & 670000 \\
\hline 26 & 1 & 1680000 & 820000 \\
\hline 27 & 1 & 3440000 & 630000 \\
\hline 28 & Trace & 1080000 & 120000 \\
\hline 29 & 1 & 1100000 & 670000 \\
\hline 30 & Trace & 1870000 & 340000 \\
\hline 31 & 1 & 1220000 & 680000 \\
\hline 32 & Trace & 1670000 & 180000 \\
\hline 33 & 1 & 2780000 & 470000 \\
\hline 34 & Trace & 3230000 & 340000 \\
\hline 35 & 1 & 2320000 & 560000 \\
\hline 36 & Trace & 3200000 & 230000 \\
\hline 37 & 2 & 2600000 & 2430000 \\
\hline 38 & Trace & 1540000 & 350000 \\
\hline 39 & 2 & 4978000 & 1504000 \\
\hline 40 & 1 & 4636000 & 1003000 \\
\hline 41 & 1 & 3711000 & 371000 \\
\hline 42 & Trace & 3767000 & 213000 \\
\hline 43 & 1 & 1525000 & 263000 \\
\hline 44 & Trace & 2699000 & 596000 \\
\hline 45 & - & 3978000 & 106000 \\
\hline 46 & 1 & 3911000 & 1494000 \\
\hline
\end{tabular}

NC: Non-consecutive fourth;

RCMT: CMT results day 7 (degree of mastitis) presencia de grumos en la secreción de leche. Con el objetivo de establecer el grado de severidad de la mastitis, se llevaron a cabo pruebas de California Mastitis Test y conteos de células somáticas para comparar la respuesta antes y después del tratamiento con quimotripsina.

Asignación de los tratamientos. Una vez identificados los animales de acuerdo con los criterios de inclusión, fueron tratados con quimotripsina a razón de $10 \mathrm{ml}$ por vía IM por animal, cada 24 horas durante 3 aplicaciones. Adicionalmente los animales recibieron amoxicilina + ácido clavulánico a razón de $15 \mathrm{mg} / \mathrm{Kg}$ vía IM cada 24 horas durante 3 días. Se manejó un grupo control con 3 animales y un total de 10 cuartos con las mismas características, que sólo recibió la aplicación de amoxicilina + ácido clavulánico sin la aplicación de quimotripsina.

Métodos de laboratorio. Para la realización de la prueba California Mastitis Test (CMT), se tomó una muestra de leche previo lavado y despunte de la glándula. Para la muestra se tomó una cantidad aproximada de $3 \mathrm{ml}$ de leche de cada cuarto sobre una bandeja de CMT de fondo negro y se agregó una cantidad igual de reactivo CMT (Masti-Test ${ }^{\circledR}$ - Laboratorios S.F.C. LTDA), agitando por 5 segundos hasta obtener la reacción. Para la clasificación del grado de mastitis de acuerdo con la prueba CMT se tomaron en cuenta los criterios descritos por Kivaria et al (27), los cuales se pueden observar en la tabla 1. Lo anterior se realizó minutos antes del tratamiento y siete días después del mismo.

A las muestras de leche, también se les realizó conteo de células somáticas utilizando un contador electrónico marca DeLaval ${ }^{\circledR}$ con gama de medición de 10000 - 4000000 células/ $\mathrm{ml}$. Estas muestras fueron tomadas después de eliminar los primeros chorros y de manera individual por cada cuarto en tubo de ensayo desde donde se hizo la medición con el contador electrónico.

\section{RESULTADOS}

En la tabla 2 se presentan los resultados de acuerdo al grado de Mastitis encontrado en el CMT y el conteo de células somáticas (CCS) antes y después del tratamiento con Quimotripsyn ${ }^{\circledR}$ y amoxicilina + ácido clavulánico. Para el análisis estadístico de los conteos de células somáticas fueron llevados a cabo análisis de varianza de dos poblaciones.

De los 46 cuartos tratados con antibiótico y la Quimotripsina, en el $100 \%$ de los casos pudieron 
Of the 46 cows treated with antibiotics and chymotrypsin, clinical improvement and decreased somatic cell count was observed in $70 \%$ of cases with statistically significant differences.

In $39(84.7 \%)$ cases, significant clinical differences were observed, mainly between what was observed before therapy and the absence of lumps in milk and a significant decrease in inflammation 7 days after starting treatment. Statistically significant differences were observed in the same number of cases in somatic cell count $(p<0.01)$ during the same period of time. The remaining number also decreased somatic cell counts and mastitis, although the response was moderate compared to that observed in the treatment group in $84.7 \%$ of the cases (Table 2 ).

Additionally, $84.7 \%$ of the animals that were treated with chymotrypsin showed an initial recovery within the first 24 hours of treatment, which could mainly be observed in body temperature. The physical examination results at 24 hours after the start of the chymotrypsin treatment showed a decrease in inflammation and even a rise in milk quality, as seen in a decrease of existing clots. It is noteworthy that the physical examination was conducted every 24 hours post-treatment for a total of 10 days.

The following are the results of the control group (Table 3 ).

The control group showed a clinical response in the CMT test in $70 \%$ of cases. In the control group no significant statistical differences regarding somatic cell count were observed before and after treatment.

Table 3. Results of the control group.

\begin{tabular}{cccc}
\hline ID & RCMT & CCS/ml day 0 & CCS/ml day 7 \\
\hline 140 AI & 2 & 3230000 & 3100000 \\
367 PD & 2 & 3890000 & 3280000 \\
678 AI & 2 & 2360000 & 2560000 \\
899 AI & 1 & 1670000 & 1780000 \\
1002 AI & 2 & 2500000 & 2380000 \\
1124 PD & 3 & 2340000 & 2300000 \\
1245 & 3 & 3410000 & 1450000 \\
1672 & 2 & 3100000 & 2380000 \\
1798 AI & 3 & 2780000 & 3450000 \\
1798 PD & 2 & 1120000 & 1340000 \\
\hline
\end{tabular}

RCMT: CMT results day 7 (degree of mastitis) evidenciarse mejoría clínica y disminución en los conteos de células somáticas con diferencias estadísticamente significativas $(p<0.05)$ a los 7 días de iniciado el tratamiento.

En 39 cuartos (84.7\%), se pudieron observar diferencias clínicas importantes, principalmente entre lo observado antes de la terapia y la ausencia de grumos en la leche y disminución significativa en la inflamación a a los 7 días de iniciado el tratamiento. En este mismo número de casos se observaron diferencias estadísticamente significativas en el conteo de células somáticas $(p<0.01)$ en el mismo período de tiempo. El porcentaje restante disminuyó también sus conteos de células somáticas y el grado de mastitis aunque la respuesta fue moderada en comparación con lo observado en el grupo del tratamiento en el $84.7 \%$ de los casos (Tabla 2). Adicionalmente, el $84.7 \%$ de los animales que fueron tratados con la quimotripsina, presentaron una recuperación inicial dentro las primeras 24 horas del tratamiento, lo que se pudo apreciar principalmente en la temperatura corporal de los animales. Los resultados en el examen físico a las 24 horas de iniciada la aplicación de quimotripsina, demostraron disminución en el grado de inflamación, incluso pudo observarse elevación en la calidad de la leche; lo anterior se pudo apreciar en la disminución de los coagulos existentes. Es importante mencionar que el examen físico se estuvo realizando cada 24 horas pos-tratamiento y durante un total de 10 días.

Los siguientes son los resultados correspondientes al grupo control (Tabla 3 ).

Por su parte, en el grupo control se observó una respuesta a nivel clínico y en la prueba de CMT en el $70 \%$ de los casos. En el grupo control no se observaron diferencias estadísticas significativas antes y después del tratamiento en cuanto al conteo de células somáticas.

\section{DISCUSIÓN}

El presente estudio se ha llevado a cabo basados en el soporte científico del mecanismo de acción de la quimotripsina (15); fármaco que aunque es utilizado con relativa frecuencia en mastitis bovina (14), hasta la fecha, no se han encontrado estudios de eficacia o reportes de caso que permitan no solo demostrar resultados clínicos, sino explicarlos desde el punto de vista de la farmacodinamia.

Para poder explicar estos resultados desde la farmacodinamia, es necesario entender que los tratamientos antibióticos por sí solos o 


\section{DISCUSSION}

This study was carried out based on scientific support of the action of chymotrypsin (15), a drug that is quite often used in bovine mastitis (14), but there were not found studies or case reports that prove the effect of this drug and clinical effectiveness.

To explain these results using pharmacodynamics, it must be understood that antibiotic treatments alone or used together with anti-inflammatory drugs can sometimes be ineffective or may take time to obtain the expected results, especially due to increased antimicrobial resistance (28). In particular, it is difficult for antibacterial substances to access some tissues, even more when inflammation is present. Mastitis treatment requires the use of drugs to accelerate recovery by breaking the fibrin capsule, with the consequent increase in the spread of antimicrobials to the inflamed tissue. Considering this, a proteolytic drug with fibrinolytic properties should be used in cases of acute bovine mastitis to facilitate penetration of antibiotics into the inflamed and infected tissue, thereby accelerating recovery of the gland.

It is known that somatic cell count is an important indicator of the degree of mastitis and a post-treatment decrease is reliable evidence of recovery. Based on this and the clinical signs observed before and after treatment as well as measurements provided by the CMT, it can be concluded that there is a positive udder health effect when chymotrypsin is applied. Significant differences in somatic cell counts between treated and control groups as well as the physical evidence of recovery (visible results on physical examination 24 hours after treatment) are important indicators that should be considered for veterinarians when treating cases of bovine mastitis.

The relationship between fast recovery of the affected glands and production improvement is directly proportional, and therefore applying a specific and opportune treatment for each type of mastitis (subclinical, acute clinical, reoccurring and/or chronic) is recommended. Treating subclinical and even clinical mastitis with chymotrypsin has advantages such as: reduction of risking evolution of subclinical mastitis to clinical phase, and milk from treated animals can be sold and milk quality can be improved by reducing the presence of somatic cells. en aplicación conjunta con antiinflamatorios, en ocasiones pueden ser ineficaces o pueden tardar en brindar los resultados esperados en especial por el hecho de la creciente resistencia a los anitimicrobianos (28). En especial, existen tejidos de difícil acceso a los antibacterianos lo que se complica cuando está presente la inflamación. La fisiopatología de la mastitis exige el uso de fármacos que permitan acelerar el curso de la recuperación mediante el rompimiento de la cápsula de fibrina y el consecuente aumento en la difusión de antimicrobianos en el tejido inflamado. Considerando lo anterior, se empleó un fármaco proteolítico en casos de mastitis aguda bovina con el fin de facilitar la penetración de antibióticos en el tejido inflamado e infectado debido a sus propiedades fibrinolíticas, acelerando así la recuperación de la glándula.

Se sabe que los conteos de células somáticas son un indicador importante del grado de mastitis y que su disminución pos-tratamiento es una evidencia confiable de la recuperación del cuarto afectado. Por lo anterior y con base en los signos clínicos observados antes y después del tratamiento, además, de las mediciones ofrecidas por el CMT, pudimos concluir que existe un efecto cuando es aplicada la quimotripsina. Las diferencias significativas en los conteos de células somáticas entre los grupos tratado y control, además, de la evidencia física de recuperación de los animales y cuartos afectos (resultados visibles en el examen físico 24 horas después del tratamiento), motivaron el registro de resultados que permitan a los Médicos Veterinarios que abordan casos de mastitis bovina, considerar este tipo de tratamientos.

La relación entre una rápida curación del cuarto afectado y la recuperación de la producción es directamente proporcional, por ello, se recomienda aplicar un tratamiento específico y oportuno para cada tipo de mastitis (subclínica, clínica aguda, reincidente y/o crónica). Entre las ventajas que representa un tratamiento de mastitis subclínica e incluso clínica con quimotripsina se encuentran las siguientes: reducción del riesgo que la mastitis subclínica evolucione hasta una fase clínica; la leche proveniente de los cuartos tratados pueda comercializarse y el mejoramiento de la calidad de la leche por reducción de las células somáticas presentes.

Adicionalmente, considerando sus propiedades, la quimotripsina, puede también ser utilizada en procesos de inflamación vascular, edemas, hematomas, abscesos, adherencias, fibromas postvacunales, mastitis, acrobustitis, metritis, infecciones respiratorias e incluso debido a su mecanismo de acción podrían ampliarse sus indicaciones, lo que sería motivo de nuevas 
Additionally, considering the properties of chymotrypsin, it can also be used in vascular inflammation processes, edemas, hematomas, abscesses, adhesions, post-vaccination fibromas, mastitis, acrobustitis, metritis, respiratory infections, which would be cause for further investigation. When it is impossible to assess the degree of fibrosis, even during acute inflammation there is an accumulation of leukocytes and fibrin (29) that leads to fibrosis of the gland. This is the key point for chymotrypsin to act by decreasing the production of fibrin, thereby allowing more effective distribution of antibiotical drugs. Therefore it is important to conclude that the use of chymotrypsin could be an adjunct in the treatment of acute mastitis.

Finally, it is also vital to clarify that it was not possible to have a control group that was completely free of treatment, due to field conditions and animal welfare. Not treating animals with acute mastitis is related to professional ethics issues.

\section{Acknowledgments}

The author thanks the Universidad de Ciencias Aplicadas y Ambientales for founding this research, as well as Laboratorios Virbac for supplying the drugs used during the investigation. investigaciones. Por otra parte, aún cuando no es posible evaluar el grado de fibrosis, si se sabe que la durante la inflamación incluso la que cursa de manera aguda, existe un proceso de acumulación de leucocitos y fibrina (29), la cual cuando se acumula durante el proceso crónico conlleva a la fibrosis de la glándula. Este es el punto clave para que la quimotripsina pueda ejercer su mecanismo de acción, al disminuir la producción de fibrina, permitiendo así la distribución más eficaz de los fármacos. Por lo anterior es importante concluir que el empleo de quimotripsina podría ser un coadyuvante en el tratamiento de la mastitis aguda, aclarando que no sería per se el responsable de la disminución de los signos clínicos.

Finalmente, también es vital aclarar que no fue posible dejar un grupo control, completamente ausente de tratamiento, debido a que el trabajo fue realizado bajo condiciones de campo y no en un laboratorio experimental. En el caso de dejar animales con mastitis aguda sin ningún tipo de terapéutica lo anterior podría cuestionarse dentro de la ética profesional.

\section{Agradecimientos}

El autor agradece a la Universidad de Ciencias aplicadas y ambientales por el apoyo a la investigación, así como a Laboratorios Virbac por haber suplido los fármacos utilizados durante la investigación.

\section{REFERENCES}

1. Petrovski KR, Trajcev M, Buneski G.A. Review of the factors affectingthe costs of bovine mastitis. J S Afr Vet Assoc 2006; 77(2):52-60.

2. Ericsson UH, Lindberg A, Persson WK, Ekman T, Artursson K, Nilsson OM et al. Microbial etiology of acute clinical mastitis and agent-specific risk factors. Vet Microbiology 2009; 137(1-2):90-7.

3. Hogeveen $\mathrm{H}$, Kamphuis C, Steeneveld W, Mollenhorst $H$. Sensors and clinical mastitis-the quest for the perfect alert. Sensors (Basel, Switzerland) 2010; 10(9):7991-8009.

4. Kim Y, Atalla H, Mallard B, Robert C, Karrow $\mathrm{N}$. Changes in Holstein cow milk and serum proteins during intramammary infection with three different strains of Staphylococcus aureus. BMC Vet Res 2011; 7(1):51.
5. Nagahata $\mathrm{H}$, Kawai $\mathrm{H}$, Higuchi $\mathrm{H}$, Kawai K, Yayou $\mathrm{K}$, Chang $\mathrm{CJ}$. Altered leukocyte responsiveness in dairy cows with naturally occurring chronic Staphylococcus aureus mastitis. J Vet Med Sci 2011; 73(7):885-94.

6. Zhao X, Lacasse P. Mammary tissue damage during bovine mastitis: causes and control. J Anim Sci 2008; 86(13):57-65.

7. Barkema HW, Schukken YH, Zadoks RN. Invited Review: The role of cow, pathogen, and treatment regimen in the therapeutic success of bovine Staphylococcus aureus mastitis. J Dairy Sci 2006; 89(6): 1877-95.

8. McDougall S, Bryan M, Tiddy RM. Effect of treatment with the nonsteroidal antiinflammatory meloxicam on milk production, somatic cell count, probability of re-treatment, and culling of dairy cows with mild clinical mastitis. J Dairy Sci 2009; 92(9):4421-31. 
9. Rantala $M$, Kaartinen L, Välimäki $E$, Stryrman M, Hiekkaranta M, et al. Efficacy and pharmacokinetics of enrofloxacin and flunixin meglumine for treatment of cows with experimentally induced Escherichia coli mastitis. J vet Pharmacol Therap 2002; 25(4):251-8

10. Banting A, Banting S, Heinonen K, Mustonen K. Efficacy of oral and arenteral ketoprofen in lactating cows with endotoxin-induced acute mastitis. Vet Rec 2008; 163:506-509

11. Fajt V, Wagner S, Norby B. Analgesic drug administration and attitudes about analgesia in cattle among bovine practitioners in the United States. J Am Vet Med Assoc 2011; 238(6):755767.

12. Ziv G, Shem-Tov M, Ascher F. Combined effect of ampicillin, colistin and dexamethasone administered intramuscularly to dairy cows on the clinico-pathological course of E. coliendotoxin mastitis. Vet Res 1998; 29(1):89-98.

13. Kania B, Kania K. Pharmacological and toxicological aspects of combination of beta-lactam and aminoglycoside antibiotic, prednisolone and procaine hydrochloride on the example of Vetramycin. Pol J Vet Sci 2003; 6(4):279-296.

14. Kruger M. Untersuchungen zum einfluss der proteolytischen enzyme trypsin, chymotrypsin und papain auf euterpathogene mikroorganismen. Tierarztl Prax 1999; 27:207215.

15. Drillich $M$, Raab D, Wittke M, Heuwieser W. Treatment of chronic endometritis in dairy cows with an intrauterine application of enzymes. A field trial. Theriogenology 2005; 63(7):1811-23.

16. Kwieciński J, Josefsson E, Jin T. Fibrinolysis is down-regulated in mouse collagen-induced arthritis, but its normalization does not alleviate the course of disease. Inflamm Res 2011; 60(11):1021-9.

17. Szaba F, Smiley S. Roles for thrombin and fibrin(ogen) in cytokine/chemokine production and macrophage adhesion in vivo. Blood 2002; 99:1053-1059.

18. Chuaqui, B., González, S. Manual de Patología General. segunda edición. Universidad Católica de Chile: Santiago de Chile; 1999

19. Levi M, Keller T, Gorp VE, Cate TH. Infection and inflammation and the coagulation system. Cardiovascular research 2003; 60:26-39.
20. Levi M, van der Poll T. Inflammation and coagulation. Critical care medicine 2010; 38(2):S26-34.

21. Biemond $B$, Levi $M$, Cate TH. Plasminogen activator and plasminogen activator inhibitor I release during experimental endotoxaemia in chimpanzees: Effect of interventions in the cytokine and coagulation cascades. Clin Sci 1995; 88:587-594.

22. Van der Poll T, Levi M, Buller H. Fibrinolytic response to tumor necrosis factor in healthy subjects. J Exp Med 1991; 174:729-732.

23. Sazonova IY, Thomas BM, Gladysheva IP, Houng K, Reed GL. Fibrinolysis is amplified by converting alpha-antiplasmin from a plasmin inhibitor to a substrate. J Thromb Haemost. 2007; 5(10):2087-94.

24. Kwieciński J, Josefsson E, Mitchell J, Higgins J, Magnusson M, Foster T, et al. Activation of plasminogen by staphylokinase reduces the severity of Staphylococcus aureus systemic infection. J Infect Dis. 2010; 202(7):1041-9.

25. Jin T, Bokarewa M, McIntyre L. Fatal outcome of bacteraemic patients caused by infection with staphylokinase-deficient Staphylococcus aureus strains. J Med Microbiol 2003; 52:919-39.

26. Guo Y, Li J, Hagström E, Ny T. Beneficial and detrimental effects of plasmin(ogen) during infection and sepsis in mice. PloS one 2011; 6(9):e24774.

27. Kivaria FM, Noordhuizen JP, Nielen M. (2007). Interpretation of California mastitis test scores using Staphylococcus aureus culture results for screening of subclinical mastitis in low yielding smallholder dairy cows in the Dar es Salaam region of Tanzania. Prev Vet Med, 2007; 78(34):274-85.

28. Oliver, S. Antimicrobial resistance of Mastitis pathogens. Vet Clin Food Anim 28 (2012) 165-185.

29. García, B. Pedro. Inflamación. Rev.R.Acad.Cienc. Exact.Fís.Nat. (Esp) Vol. 102, No. 1, pp 91-159, 2008 IX Programa de Promoción de la Cultura Científica y Tecnológica. 